André Murbach Maidl

\title{
Typed Lua: An Optional Type System for Lua
}

\section{TESE DE DOUTORADO}

Thesis presented to the Programa de Pós Graduação em Informática of the Departamento de Informática, PUC-Rio as partial fulfillment of the requirements for the degree of Doutor em Informática

Advisor : $\quad$ Prof. Roberto lerusalimschy Co-Advisor: Prof. Fabio Mascarenhas de Queiroz 


\section{Typed Lua: An Optional Type System for Lua}

Thesis presented to the Programa de Pós Graduação em Informática, of the Departamento de Informática do Centro Técnico Científico da PUC-Rio, as partial fulfillment of the requirements for the degree of Doutor.

Prof. Roberto lerusalimschy

Advisor

Departamento de Informática — PUC-Rio

Prof. Fabio Mascarenhas de Queiroz

Co-Advisor

UFRJ

Prof. Ana Lúcia de Moura

Departamento de Informática — PUC-Rio

Prof. Edward Hermann Haeusler Departamento de Informática — PUC-Rio

Prof. Anamaria Martins Moreira

UFRJ

\section{Prof. Roberto da Silva Bigonha UFMG}

Prof. José Eugênio Leal Coordinator of the Centro Técnico Científico da PUC-Rio 
All rights reserved.

\section{André Murbach Maidl}

The author graduated in Computer Science from Pontifícia Universidade Católica do Paraná - PUCPR in 2004, and obtained the degree of Mestre at Universidade Federal do Paraná - UFPR in 2007. He obtained the degree of Doutor at PUCRio in 2015, where he worked in the field of programming languages.

Bibliographic data

Maidl, André Murbach

Typed Lua: An Optional Type System for Lua / André Murbach Maidl; advisor: Roberto lerusalimschy; co-advisor: Fabio Mascarenhas de Queiroz. - 2015.

149 f. : il. ; $30 \mathrm{~cm}$

Tese (doutorado) - Pontifícia Universidade Católica do Rio de Janeiro, Departamento de Informática, 2015.

Inclui bibliografia.

1. Informática - Teses. 2. Linguagens de script. 3. Lua. 4. Sistemas de tipos. 5. Sistemas de tipos opcionais. 6. Tipagem gradual. I. lerusalimschy, Roberto. II. Queiroz, Fabio Mascarenhas de. III. Pontifícia Universidade Católica do Rio de Janeiro. Departamento de Informática. IV. Título. 


\section{Acknowledgments}

First of all I would like to thank three indispensable people in my life: my wife, my mother, and my father. Izabella is my inexhaustible source of inspiration, and she is always pushing me forward. My mother is a very brave person, and she inspires me to never give up. My father is a very kind person, and he inspires me to try being more sensitive. I am thankful to them not only because the support they gave me while writing this thesis, but also because they are the reason of my life.

This work would have not happened without all the help from my advisors. Roberto has a singular view of computer science that pushed me to pursuit the best I could do, while Fabio gave me the confidence I needed about the work we were doing. I am glad that both of them had patience to guide me through this work, and for all the nice meetings we had that led me to learn a lot of new concepts and ideas.

It is hard to complete a thesis without having some leisure moments, so I thank my friend and roommate André Ramiro for all the crazy and fun moments that we had, which helped me to keep focused during working hours.

I also thank my friends at LabLua for the nice work environment, specially Hisham and Pablo for all the support during the hardest moments.

It may look easy moving to Rio, as it is a sunny place with lots of things to do, but it may not be as easy as it looks for someone that grew up in a cloudy and rainy town. Thus, I thank my cousin Rebecca and my aunt Nazira for all the help and affection they gave me during my adaptation in Rio, which were fundamental to keep my goals in mind.

I thank the guys from Rio de Janeiro Fixed Gear (RJFG) for all the fun we had during the night rides, and for helping me to discover Rio.

I am also most grateful to the professors Ana Lúcia de Moura, Anamaria Martins Moreira, Edward Hermann Haeusler, and Roberto da Silva Bigonha for their careful review that helped to improve this work.

Finally, I would like to thank CAPES, Google Summer of Code, and PUC-Rio for partially funding this work. 


\section{Abstract}

Maidl, André Murbach; Ierusalimschy, Roberto (Advisor); Queiroz, Fabio Mascarenhas de (Co-Advisor). Typed Lua: An Optional Type System for Lua. Rio de Janeiro, 2015. 149p. Doctoral Thesis - Departamento de Informática, Pontifícia Universidade Católica do Rio de Janeiro.

Dynamically typed languages such as Lua avoid static types in favor of simplicity and flexibility, because the absence of static types means that programmers do not need to bother with abstracting types that should be validated by a type checker. In contrast, statically typed languages provide the early detection of many bugs, and a better framework for structuring large programs. These are two advantages of static typing that may lead programmers to migrate from a dynamically typed to a statically typed language, when their simple scripts evolve into complex programs. Optional type systems allow combining dynamic and static typing in the same language, without affecting its original semantics, making easier this code evolution from dynamic to static typing. Designing an optional type system for a dynamically typed language is challenging, as it should feel natural to programmers that are already familiar with this language. In this work we present and formalize the design of Typed Lua, an optional type system for Lua that introduces novel features to statically type check some Lua idioms and features. Even though Lua shares several characteristics with other dynamically typed languages such as JavaScript, Lua also has several unusual features that are not present in the type system of these languages. These features include functions with flexible arity, multiple assignment, functions that are overloaded on the number of return values, and the incremental evolution of record and object types. We discuss how Typed Lua handles these features and our design decisions. Finally, we present the evaluation results that we achieved while using Typed Lua to type existing Lua code.

\section{Keywords}

Scripting languages; Lua; Type systems; Optional type systems; Gradual typing 


\section{Resumo}

Maidl, André Murbach; Ierusalimschy, Roberto; Queiroz, Fabio Mascarenhas de. Typed Lua: um sistema de tipos opcional para Lua. Rio de Janeiro, 2015. 149p. Tese de Doutorado Departamento de Informática, Pontifícia Universidade Católica do Rio de Janeiro.

Linguagens dinamicamente tipadas, tais como Lua, não usam tipos estáticos em favor de simplicidade e flexibilidade, porque a ausência de tipos estáticos significa que programadores não precisam se preocupar em abstrair tipos que devem ser validados por um verificador de tipos. Por outro lado, linguagens estaticamente tipadas ajudam na detecção prévia de diversos bugs e também ajudam na estruturação de programas grandes. Tais pontos geralmente são vistos como duas vantagens que levam programadores a migrar de uma linguagem dinamicamente tipada para uma linguagem estaticamente tipada, quando os pequenos scripts deles evoluem para programas complexos. Sistemas de tipos opcionais nos permitem combinar tipagem dinâmica e estática na mesma linguagem, sem afetar a semântica original da linguagem, tornando mais fácil a evolução de código tipado dinamicamente para código tipado estaticamente. Desenvolver um sistema de tipos opcional para uma linguagem dinamicamente tipada é uma tarefa desafiadora, pois ele deve ser o mais natural possível para os programadores que já estão familiarizados com essa linguagem. Neste trabalho nós apresentamos e formalizamos Typed Lua, um sistema de tipos opcional para Lua, o qual introduz novas características para tipar estaticamente alguns idiomas e características de Lua. Embora Lua compartilhe várias características com outras linguagens dinamicamente tipadas, em particular JavaScript, Lua também possui várias características não usuais, as quais não estão presentes nos sistemas de tipos dessas linguagens. Essas características incluem funções com aridade flexível, atribuições múltiplas, funções que são sobrecarregadas no número de valores de retorno e a evolução incremental de registros e objetos. Nós discutimos como Typed Lua tipa estaticamente essas características e também discutimos nossas decisões de projeto. Finalmente, apresentamos uma avaliação de resultados, a qual obtivemos ao usar Typed Lua para tipar código Lua existente.

\section{Palavras-chave}

Linguagens de script; Lua; Sistemas de tipos; Sistemas de tipos opcionais; Tipagem gradual 


\section{Contents}

1 Introduction $\quad 11$

2 Blending static and dynamic typing $\quad 15$

2.1 A little bit of history 15

$\begin{array}{ll}2.2 & \text { Optional Type Systems } \\ & 17\end{array}$

$\begin{array}{lll}2.3 \text { Gradual Typing } & 18\end{array}$

2.4 Approaches that are often called Gradual Typing 23

2.5 Statistics about the usage of Lua 24

3 Typed Lua $\quad 29$

$\begin{array}{lll}3.1 & \text { Optional type annotations } & 30\end{array}$

3.2 Functions 35

$\begin{array}{lll}3.3 & \text { Unions } & 38\end{array}$

3.4 Tables 42

3.5 Type aliases and interfaces 48

$\begin{array}{lll}3.6 & \text { Modules } & 51\end{array}$

3.7 Object-Oriented Programming 54

$\begin{array}{lll}3.8 & \text { Description files } & 58\end{array}$

$\begin{array}{lll}4 & \text { The type system } & 61\end{array}$

4.1 Types 61

4.2 Subtyping 65

$\begin{array}{lll}4.3 & \text { Type checking } & 73\end{array}$

5 Evaluation $\quad 92$

5.1 Lua Standard Library $\quad 94$

$\begin{array}{lll}5.2 & \text { MD5 } & 97\end{array}$

$\begin{array}{lll}5.3 \text { LuaSocket } & 98\end{array}$

$\begin{array}{llr}5.4 & \text { LuaFileSystem } & 99\end{array}$

5.5 HTTP Digest 100

$\begin{array}{lll}5.6 & \text { Typical } & 100\end{array}$

5.7 Modulo $11 \quad 101$

5.8 Typed Lua Compiler 102

6 Related Work 104

$\begin{array}{lll}6.1 & \text { Other Lua projects } & 104\end{array}$

$\begin{array}{lll}6.2 & \text { Other projects } & 106\end{array}$

$\begin{array}{lll}7 & \text { Conclusions } & 109\end{array}$ 
$\begin{array}{ll}\text { A Glossary } & 120\end{array}$

$\begin{array}{ll}\text { B The syntax of Typed Lua } & 123\end{array}$

C The type system of Typed Lua $\quad \mathbf{1 2 6}$

C.1 Subtyping rules 126

$\begin{array}{ll}\text { C.2 Typing rules } & 130\end{array}$

$\begin{array}{lll}\text { C.3 Auxiliary functions } & 144\end{array}$ 


\section{List of Figures}

2.1 Syntax of the gradually-typed lambda calculus $\quad 19$

$\begin{array}{lll}2.2 & \text { The consistency relation } & 19\end{array}$

2.3 Gradual type system gradually-typed lambda calculus 20

$\begin{array}{lll}2.4 & \text { The subtyping relation } & 21\end{array}$

2.5 The consistent-subtyping relation 21

3.1 The concrete syntax of Typed Lua types 30

3.2 The concrete syntax of Typed Lua function types 36

3.3 The concrete syntax of Typed Lua table types 43

3.4 The concrete syntax of Typed Lua type aliases 48

3.5 The concrete syntax of Typed Lua interfaces 49

3.6 The concrete syntax of Typed Lua description files 59

4.1 The abstract syntax of Typed Lua types 62

4.2 The special types used by Typed Lua 65

$\begin{array}{lll}4.3 & \text { The abstract syntax of Typed Lua } & 74\end{array}$ 


\section{List of Tables}

2.1 Summary of the statistics about the usage of Lua 28

5.1 Evaluation results for each case study 93

5.2 Evaluation results for Lua Standard Library 95

\begin{tabular}{ll}
5.3 & Evaluation results for MD5 \\
\hline
\end{tabular}

5.4 Evaluation results for LuaSocket 98

5.5 Evaluation results for LuaFileSystem 100

5.6 Evaluation results for HTTP Digest 100

5.7 Evaluation results for Typical 100

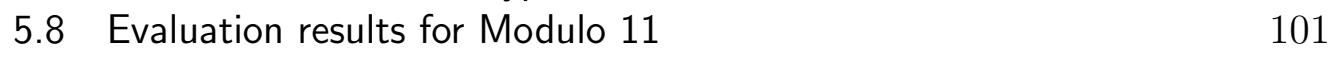

5.9 Evaluation results for Typed Lua Compiler 102 